\title{
Manchester ou Tombuctu? A economia da "cidade grega" segundo os positivistas
}

\author{
JOSÉ ANTONIO DABDAB TRABULSI \\ Faculdade de Filosofia e Ciências Humanas \\ Universidade Federal de Minas Gerais
}

\begin{abstract}
RESUMO: Este trabalho tem por objetivo estudar a visão dos historiadores "positivistas" da cidade grega, em especial em matéria de economia. Assim, parece que, contrariamente a uma idéia consagrada, a cidade grega desses autores seria já primitivista ou pelo menos em grande parte primitivista. Mas não existe unanimidade entre eles. Tentamos também perceber algumas das motivações das escolhas por eles realizadas. Este texto é parte de um conjunto de trabaIhos do século XX, sobre as "cidades gregas". Ele foi escrito com o auxílio da Capes.
\end{abstract}

PALAVRAS-CHAVE: Cidade grega; historiografia; positivismo; história grega; pensamento francês.

Na segunda metade do século XX, tornou-se freqüente começar os trabalhos de história em geral e de história grega em especial, com uma crítica mais ou menos acerba, mais ou menos desdenhosa, das maneiras e práticas "positivistas". Essa atitude chegou a se constituir em uma moda, um reflexo, quase uma obrigação para quem quisesse ser levado a sério. A reação anti-positivista foi tanto mais violenta quanto, ao longo de toda a primeira metade do século XX, a abordagem, que nos nossos meios é freqüentemente identificada com o "humanismo tradicional", foi dominante e até hegemônica, na área de expressão francesa ainda mais que em outras. Weber era pouco conhecido e pouco discutido, o marxismo limitado a um canto pouco ou nada frequientado por historiadores da antiguidade, muito conservadores, e a antropologia praticada apenas por marginais ou "loucos simpáticos" como Jeanmaire ou Gernet, rejeitados para as margens do sistema.

Neste fim de século, a moda mudou, e começa-se a dizer que os positivistas foram denegridos e que se exagerou e se desnaturou o que eles disseram, com o objetivo de desqualificá-los. O que é exato, com muita freqüência, mas não é suficiente para explicar esta nova atitude. Volta a um modelo abandonado, para melhor sair dos modelos que o substituíram, e que por sua vez aparecem hoje como insuficientes? Convergência real de opiniões com elementos de um método, senão de uma ideologia, neste fim de século de "restauração"? 
O que é certo, em todo caso, é que, no que se refere aos trabalhos sobre a cidade grega, quer seja para criticar ou para relativizar as críticas, falou-se sem saber muito bem o quê, pois há muito aqueles autores não são mais lidos. Toda uma geração - a minha - foi formada com textos que recusavam a contribuição desses autores. É a razão pela qual eu penso ser útil propor um estudo "literal" da cidade grega "positivista". Tomo este termo no seu uso corrente, tal como ele é entendido nos meios dos estudos clássicos, sem preocupação de rigor filosófico. Considero o conjunto da produção, mas limito a análise à primeira metade do século, enquanto esta análise foi aplicada "sem complexo", pois depois o ataque foi tão forte que até os positivistas se negavam a aplicar o modelo. Houve um positivismo "envergonhado" - mas isto parece quase terminado hoje - que não se presta tão bem à análise. Mas eu não renuncio a tentar observar o que, já durantes os anos de glória, anuncia o declínio fulminante desta abordagem, que marcou uma época em que os estudos gregos tinham ainda um impacto muito forte (ainda que em diminuição rápida) sobre as ciências humanas.

Este texto propõe a análise de um aspecto particular, a saber, a natureza moderna ou primitiva da economia da cidade grega, segundo os autores positivistas, e tenta perceber algumas das motivações de suas escolhas. Ele é parte de um conjunto mais vasto, onde em várias obras, tento estudar diversos aspectos da cidade grega dos positivistas; aspectos de configuração, mas também aspectos de ideologia ou de método. Como a produção é enorme, para poder realizar um estudo atento aos textos, foi necessário escolher. Tentei fazer uma escolha que fosse variada, mas representativa do equilíbrio de influência e de notoriedade que existia na época. Assim, certos autores estão mais presentes, como Francotte, Jardé, Cloché, Glotz ou os dois Croiset. Como a minha intenção é a de estabelecer, a longo prazo, uma avaliação, uma comparação entre as diversas "cidades gregas", os paralelos, as analogias, as confrontações, as antecipações em relação a autores mais recentes são freqüentes e voluntárias. Parece-me desejável fazer uma historiografia da cidade grega que seja ao mesmo tempo e na medida do possível uma história da cidade grega, senão até uma proposição de cidade grega.

Ao longo de toda a primeira metade do século XX, na bibliografia positivista, o estudo da economia da cidade grega foi dominado pela questão de se saber se essa economia era "moderna" ou "primitiva". Entre Manchester e Tombuctu, poderiam eles ter-se perguntado onde situar a cidade grega em geral e Atenas em especial? Examinemos, portanto, esse problema por etapas.

A agricultura, inicialmente. Jardé, grande especialista de questões agrícolas antigas, tem uma visão primitivista da agricultura grega. A agricultura era rotineira, os eventuais progressos unicamente empíricos, como em geral ocorria antes do século XIX, e "temos a impressão de que a antiguidade grega não fez qualquer esforço metódico para melhorar as espécies por seleção, cruzamento ou aclimatação" (Jardé, 1925, 14). É difícil avaliar os rendimentos, e Jardé é obrigado a reconhecê-lo após muito esforço de erudição, mas ele estima que se trata de uma agricultura "que se contenta com rendimentos à beira da insuficiência" e que nós estamos "muito longe da cultura intensiva" (Jardé, 1925, 60). Os solos eram em média pobres, "a Ática terá sempre uma produção de cereais fraca que, desde muito cedo, não mais será suficiente para as necessidades da população". Essa pobreza, 
entretanto, "tornou os gregos industriosos e os levou a tirar do seu solo o melhor possível". Afolhamento bienal das terras, predomínio dos cereais, raros prados, culturas industriais quase inexistentes, poucos legumes, vários elementos caracterizam uma agricultura pobre (Jardé, 1925, 61-81). Para Jardé, a tendência à divisão da propriedade fragiliza os pequenos proprietários e os coloca nas mãos dos credores, e os marcos hipotecários simbolizam esta dependência (sabemos que Finley verá neles outra coisa bem diferente). Há grandes proprietários, mas poucas grandes propriedades, já que as superfícies eram fragmentadas, o que resulta no fato de que as práticas de cultivo também não evoluíam entre os grandes proprietários, e os rendimentos da agricultura também não (Jardé, 1925, 121). Jardé insiste no caráter muito hipotético dos cálculos sobre a "procura" de cereais, tendo em vista a dificuldade em estimar a população, mesmo no caso de Atenas. Ele critica muito os argumentos de L. Gernet, e mostra as armadilhas dos sistemas de avaliação. Entretanto, ele próprio faz cálculos (consumo anual por habitante, superfícies, rendimento agrícola, etc.), e estima que "o déficit alimentar começaria assim que a densidade de população ultrapassasse 36 por quilômetro quadrado", o que era aproximadamente a densidade populacional da Grécia do final do século XIX, época em que ela importava grãos. Ora, a Grécia antiga era mais povoada e, sobretudo, se uma região possuía uma grande cidade, como Atenas ou Corinto, o déficit se tornava logo muito sensível (Jardé, 1925, 123-143).

Para Jardé, o rendimento da terra era fraco, entre 8 e 12\%, ligeiramente superior às taxas de retorno de investimento em terras. O que significa que ele era medíocre, pois o dinheiro podia render até $30 \%$; mas era preferido pois era menos arriscado e gerava mais prestígio (Jardé, 1925, 145-162). A agricultura não evoluiu: se é verdade que houve até o século VI um lento recuo das florestas e um aumento das culturas arbustivas, a partir do século V a situação não evoluiu mais. É verdade que, para Jardé, as insuficiências da agricultura grega são as da natureza mais que as dos homens; por exemplo, as limitações do transporte terrestre (ausência de estradas, geografia acidentada, arreios e atrelamento insuficientes) fazem com que um barco bem grande transporte uma carga equivalente à de 520 charretes ou 2.600 mulas! Dessa forma, os grãos importados chegam de muito longe por mar, muito mais que dos eventuais excedentes das cidades vizinhas, o que limita o estímulo econômico para produzir (Jardé, 1925, 190-197). Mas ele pensa que "com frequência temse a tendência a exagerar a importância do problema alimentar". Na maioria das cidades, entre os povos gregos "sem história", "todos ou quase todos, com suas colheitas medíocres, conseguiam [...] bastar-se a si próprios". O camponês "vivia sobriamente" dos frutos do seu domínio (pão, maza, cebola, figo, azeitona, vinho), "sem se preocupar com as expedições de grão do Ponto ou da Sicília, com a cotação das farinhas nos mercados de Rodes ou do Pireu, com as generosidades anonárias dos arcontes do Bósforo ou com a política de especulação de Cleômenes, sátrapa do Egito" (Jardé, 1925, 198-200). Portanto, segundo Jardé, o equilíbrio geral é o de uma agricultura pobre, sem progresso, e largamente predominante no conjunto da economia grega. Com efeito, "a agricultura permaneceu sempre aos olhos dos gregos a ocupação principal e a principal fonte de rendimentos" (Jardé, 1923, 56) e "a população se compunha, na maioria, de camponeses" (Jardé, 1914, 241); e, "como em todas as economias ainda pouco desenvolvidas, o cultivador grego procura ter em sua terra tudo o que ele precisa". É apenas nas grandes cidades que o problema da subsistência se torna "uma das razões determinantes da política externa" (Jardé, 1923, 56-63). 
Esta visão de uma agricultura primitiva é largamente predominante ao longo da primeira metade do século. Mesmo um Glotz, que vê uma agricultura ateniense em constante progresso técnico, do século V ao IV, o que, através da exportação de vinho e de azeite, tornava a terra mais móvel, aderia a muitos outros traços "primitivos". Assim, para Glotz, ainda que sua importância relativa tenha diminuído, "a terra permanece o único meio de existência num grande número de países e o principal recurso dos cidadãos mesmo num país tão resolutamente dedicado ao comércio marítimo quanto a Ática", situação que não parece agradar-lhe, já que ele qualifica as preferências dos antigos pela terra como "preconceito fisiocrático" (Glotz, 1920, 294-295). As “carências" da agricultura são expressas por formulações como esta: as propriedades eram pequenas na Ática e constituídas de parcelas esparsas, o que não permitia "reduzir os custos gerais e organizar a cultura em larga escala" (Glotz, 1920: 300). Outro sinal de não-desenvolvimento: a maior parte dos cultivadores habita o campo e trabalha a terra com o auxílio de um "proletariado rural" (Glotz, 1920, 306), já que a agricultura fazia "um emprego muito reduzido da mão de obra servil"; "assim, a população servil era insignificante nas regiões agrícolas, [...] a Ática tinha poucos escravos rurais" (Glotz, 1920, 244-245).

Seria fácil multiplicar os exemplos ao infinito. Hatzfeld fala da Grécia, "esta sociedade que tem por base a agricultura" (Hatzfeld, 1926, 53). Para Laurent, "as cidades jamais deixaram de olhar a terra, mesmo as mais marítimas", e, se não se deve tomar Corinto, Mileto ou Atenas como exemplos, pois se trata de exceções, "se fosse possível comparar a soma de riqueza fornecida pela exploração do solo com aquela que se tirava do tráfico e da especulação propriamente dita, veríamos certamente que a primeira era de longe a mais considerável" (Laurent, 1933, 99-100). Posição tanto mais significativa quando Laurent fala do comércio, da indústria e do "capitalismo" ateniense (Laurent, 1933, 102). Para Aymard, entretanto, mais permeável a certos elementos de modernismo, "esta economia diversificada só supera a economia rural em raros pontos das regiões gregas", e no conjunto a vida rural predomina (Aymard, 1953, 325). Dizer que ela "supera", mesmo em relação a Siracusa, Corinto ou Atenas, é como cair numa "tentação modernista", tão fortes permanecem, em geral, as convicções primitivistas.

Para irmos além de Glotz e Aymard, para encontrarmos realmente convicções modernistas neste domínio, é preciso retornar a P. Guiraud, que ainda escreve no início do século XX, mas que pertence de fato a uma geração que precede a de Glotz ou Gernet. Quando Guiraud explica a dependência de Atenas em grãos, ele diz: "jamais os ingleses vigiaram a rota das Índias com um olhar mais ciumento que os atenienses a do Bósforo", e fala dos imperativos econômicos da política ateniense. O que será uma exceção nos primitivistas é, para Guiraud, um exemplo normal, representativo do conjunto da política ateniense.

Portanto, num conjunto econômico dominado pela agricultura, esta última é, ela própria, rotineira e pouco produtiva. Duas vezes primitiva.

Depois da agricultura, a indústria. Trata-se de um domínio capital no debate sobre a natureza da economia antiga, como mostram os grandes trabalhos escritos por Francotte ou Glotz. O próprio P. Cloché, que não é um especialista em economia, se vê obrigado a escrever um longo capítulo sobre "a vida industrial" (Cloche, 1931, 27-73), sinal da importância e até da preponderância das preocupações industriais em relação aos outros setores, no início do século XX. 
Os autores constatam freqüentemente a diversidade de situações, como por exemplo Jardé: "a indústria se desenvolveu mais ou menos de acordo com as cidades. Nos Estados aristocráticos, os cidadãos pensam se rebaixar se exercerem uma profissão: os espartanos deixam aos periecos o comércio e a indústria. Em Atenas, pelo contrário, o trabalho é honrado; uma lei de Sólon ordena ao pai que forneça ao filho o aprendizado de uma profissão. Os pequenos patrões trabalham eles próprios no seu negócio com um ou dois operários, que são o mais das vezes cidadãos. Há também grandes oficinas, onde se empregam de preferência escravos, como a fábrica de armas que possuía o pai de Demóstenes. Nas aldeias, o mesmo trabalhador exerce vários ofícios; nas grandes cidades, a divisão do trabalho é levada muito longe [...]" (Jarde, 1914, 241). A grande questão será encontrar qual é o equilíbrio geral nesta diversidade.

Segundo Hatzfeld, a indústria tinha "um aspecto modesto"; mão-de-obra barata, multiplicidade de oficinas. Apenas as minas e a construção naval tinham uma dimensão maior. A produção era dominada pela pequena oficina, que era muitas vezes também, ao mesmo tempo, a pequena loja. Nada de produção em série, nada de estoques, nada de grandes capitais. E, "neste sistema econômico que guarda, apesar de sua properidade, tantos traços de arcaísmo, uma inovação é uma conquista definitiva, pelo menos nas cidades marítimas; é o uso de uma moeda cômoda". Temos a impressão de que, para Hatzfeld, as poucas "inovações" não pesam o mesmo que os "traços de arcaísmo", pois ele diz claramente que "sem dúvida, e jamais o repetiremos demais, é imprudente querer representar-se a indústria e o comércio em Atenas, no século $\mathrm{V}$, sob o aspecto em que os vemos hoje nos países civilizados" (Hatzfeld, 1926, 138-142). Hatzfeld parece primitivista sem exageros.

J. Laurent, que se apóia muitas vezes em Guiraud, pensa que a indústria existe, é variada, mas não muito importante, salvo nas minas. A indústria "nunca foi muito importante. Ela foi pequena; ela não se constituiu na força essencial do país; ela fez viver alguns empresários e muitos artesãos. Se ela não provocou o surgimento do proletariado e do pauperismo, já que sua mão-de-obra foi principalmente servil, ela não teve poderes para diminuir o pauperismo produzido por outras causas. Ela teve apenas suficientemente a importância social de agrupar os miúdos, para contribuir, com o comércio, para colocar, face aos cultivadores, a massa dos que não viviam do solo" [...] (Laurent, 1933, 139).

Tratemos agora do próprio Guiraud, que influenciou muitos autores do início do século XX, e, especialmente, Glotz. Já Guiraud, é verdade, se vê obrigado a um mínimo de primitivismo na sua dosagem. Assim, "havia em Atenas uma multidão de pequenos artesãos, exercendo mais ou menos todas as profissões [...] o artesão trabalhava quase sempre para o Estado ou para o público; era raro que ele fosse contratado por um patrão", "as oficinas nunca eram muito grandes na Ática" e "podemos afirmar que a grande indústria, no sentido atual da palavra, foi ignorada pelos Gregos. Suas aglomerações operárias não eram comparáveis às nossas. Eles possuíram oficinas, mas não manufaturas; primeiramente porque, em lugar de nossas poderosas máquinas, eles se contentaram com um instrumental muito simples, sem nem teram tido a idéia de solicitar à natureza sua força motriz, e, em segundo lugar, porque as fortunas individuais eram normalmente bastante medíocres e não se formavam associações de capitais" (Guiraud, 1905, 58-59). Apesar da constatação de base (indústria fraca), Guiraud é tão pouco primitivista que ele escolhe muito mal seus 
argumentos, pois não é certamente devido a uma "falta de idéias" ou a uma "incapacidade de associar-se" que podemos atribuir a situação que ele descreve.

Ao contrário, quando se trata de elementos modernos, ele avança com gosto; acerca do poder de comando político, por exemplo: "entre os personagens que desempenharam um papel na história de Atenas, no fim do século V, vários eram industriais", como Cleon, Hyperbolos ou Cleofonte. Ele pinta um quadro verdadeiramente "manchesteriano" da economia grega, com todo tipo de encorajamento ao trabalho, ao ensino das profissões, à importação de mão-de-obra. E, mais ainda, "toda a política externa de Atenas foi dominada pela preocupação de buscar fora as matérias-primas e de buscar mercados. As colônias que ela fundou, as aquisições territoriais que ela fez, o império marítimo que ela criou no século $\mathrm{V}$ antes de Jesus Cristo e que ela tentou restaurar no século IV, tudo isto tinha por objetivo servir os interesses da indústria e da classe industrial" (Guiraud, 1905, 51-61). As relações entre indústria e império são pensadas como sendo as mesmas do mundo contemporâneo. Da mesma maneira, acerca do imposto: "a Ática dos séculos V e IV não era um desses países onde predomina a propriedade fundiária e onde o imposto sobre o capital é antes de tudo um imposto sobre a terra. O solo era lá um elemento das fortunas privadas, mas não era o único. Numa cidade onde a indústria, o comércio, os bancos, a navegação eram tão ativos, era inevitável que a riqueza mobiliária fosse preponderante ou pelo menos que ela se equilibrasse com a outra". Sua maneira de lançar este "preponderante" é um sinal claro do seu modernismo. Outro sinal de modernismo, o número de metecos, que se "dedicavam à indústria e ao comércio" e que eram mais numerosos nas cidades ricas, "portos marítimos", "centros de grande produção", "cidades de grande tráfico", mas que tinham um grande espaço "na maior parte das cidades". Em Atenas, havia 100.000 para 120.000 cidadãos no final do século V (Guiraud, 1905, 77-134). Fazer uma avaliação tão elevada do número de metecos é uma maneira de reforçar a importância da indústria e do comércio.

Com Francotte, o panorama muda. Ele só vê três indústrias "que tomaram algum desenvolvimento": a cerâmica, a lã e os metais. Portanto, o campo de uma eventual grande indústria se encontra limitado desde o início (Francotte, 1900, v1, 55). Das três, para Francotte, a mais considerável é a cerâmica. Ele examina a controvérsia em torno da produção ou importação de vasos, e estima: "eu não vejo traços de uma indústria intensa; eu não vejo essas usinas, essas oficinas lançando em grande número os produtos de algumas cidades sobre a imensa maioria das cidades gregas, que permanecem passivas. Eu não encontro, na esfera econômica, o fato que é afirmado na esfera estética, e se me fosse permitido tomar posição neste debate, sem negar a grande influência das escolas coríntias, jônicas, atenienses, eu seria tentado a reduzir muito a atividade industrial de seus artistas"; e ele contesta a idéia segundo a qual Atenas se tenha ornado uma "cidade manufatureira" (Francotte, 1900, v1, 73-74). Um dos méritos de Francotte é o de sempre se colocar a questão da importância relativa das ocupações, das atividades, e não simplesmente afirmar a existência de uma atividade porque existe uma fonte a seu respeito. Ele chega a criticar trabalhos anteriores ao seu como inventários onde as coisas freqüentes e os casos isolados estão em igualdade. Assim, acerca da cerâmica, ele gostaria de "poder medir a importância desta indústria num de seus centros: quantos operários ela ocupava, ela era produtiva?" Ora, "as inscrições áticas só citam um número muito pequeno de ceramistas. Conhecemos cinco ou seis" e compreenderíamos dificilmente "que uma indústria próspera possa permanecer o monopólio de es- 
trangeiros e bárbaros" (numa abordagem que ignora o que outros autores chamarão os "bloqueios psicológicos"). E sua conclusão sobre a cerâmica é sem equívoco: "coisa singular, uma indústria, que levou tão alto a glória de Atenas, não deixou, na sua história, a não ser traços insignificantes. Não seria porque o resultado obtido não está em proporção com a fraqueza dos meios empregados? Algumas gerações de artistas e um pequeno número de oficinas foram suficientes para que a cidade adquirisse uma glória imortal. Coloque ao lado das oficinas, as fábricas dos ceramistas que trabalham para a clientela comum e se terá uma indústria que, sem empregar muitos braços, pode satisfazer a todas as necessidades" (Francotte, 1900, v1 , 76-77). Ora, se a indústria mais importante da cidade mais importante emprega tão poucos braços, imagine-se o resto...

O resto, é a indústria da lã que, "importante em toda parte, era sobretudo doméstica", e a metalurgia, que é "hoje de todas as indústrias a mais ativa", mas que, na Antiguidade, salvo em relação às armas, os móveis, alguns instrumentos e objetos de arte, não tinha a mesma importância. Aliás, se nós podemos constatar uma difusão bastante considerável da metalurgia", "infelizmente, ainda aqui faltam as indicações sobre a força deste ramo da indústria" (Francotte, 1900, v1, 77-92). Aliás, "uma sociedade onde o ideal é o de viver de rendas não é uma sociedade onde a indústria é florescente" (Francotte, 1900, v1, 259), o que é (em 1900) muito bem dito.

Possibilidades existiam: em Atenas, "algumas exceções atestam um progresso maior: a fábrica de Lísias, as duas fábricas do pai de Demóstenes, a fábrica de Pásion, não são mais simples oficinas: elas ocupam um número bastante grande de escravos e empregam capitais bem grandes. Aparentemente, a Antiguidade possuía, com a escravidão, o meio de criar facilmente a grande indústria [...] ela, ao contrário, contribuiu para manter a organização por profissões e proteger os pequenos patrões contra os grandes" (Francotte, 1900, v1, 307). Aliás, "a concorrência entre o trabalho servil e o trabalho livre foi muito menos importante do que se diz com frequiência e [...] para resistir a ele (o trabalho servil), o trabalho livre não precisou do apoio do Estado" (Francotte, 1900, v1, 263).

Em resumo, para Francotte, a indústria grega "se afasta consideravelmente da indústria moderna"; "não é exato dizer que entre a organização econômica da Antigüidade e a de hoje, há uma simples diferença do mais ao menos, que a Grécia antiga era, em pequena escala, deste ponto de vista, o que seria, em grande escala, um dos nossos Estados modernos. Já é significativo reconhecer esta diferença de quantidade: ela se acompanha, se posso dizer, de uma diferença de qualidade" (Francotte, 1900, v1, 263). Portanto, diferença de quantidade e de qualidade. Essa formulação é não apenas primitivista, mas também (quase) weberiana.

Falta examinar, em relação à indústria grega, o caso Glotz. Com ele, é preciso estar atento às diversas épocas. A indústria da época homérica "dá a idéia de um desenvolvimento ainda bem medíocre". Não devemos nos enganar com a presença de artesãos na epopéia, pois "na realidade, a vida social faz ao trabalho e à cada profissão em particular condições que tornam impossível toda produção em larga escala" (Glotz, 1920, 55-60), observação sociologicamente interessante, observe-se de passagem.

Em seguida, e até meados do século VIII, a indústria esteve em atraso. Mas então "as metrópoles deveram fornecer às colônias, sempre mais numerosas e mais ricas, armas e 
utensílios, tecidos, vasos de toda espécie. Logo, as colônias servindo de depósitos ou fabricando por sua vez, a Grécia precisou responder à demanda crescente dos povos bárbaros. Foram a colonização e o comércio que puseram a indústria em movimento". Então, "a descoberta de um procedimento técnico faz a fortuna de um indivíduo e contribui para o poderio de uma cidade" (Glotz, 1920, 154-156). A valorização do aspecto mercantil da colonização arcaica é sem dúvida um elemento de modernismo, mas aqui Glotz vai muito longe, e é toda a imagem da expansão européia que vemos por detrás de sua análise.

Glotz vê "progressos da técnica" que introduzem na indústria "uma especialização cada vez mais rigorosa", sobretudo na cerâmica, indústria "muito ativa" onde "cada tipo de trabalho se aperfeiçoa o suficiente para exigir uma aprendizagem particular", numa imagem de indústria moderna. Acabou o artesão viajante: a uma demanda internacional corresponde uma divisão do trabalho internacional"; tendo o artesão necessidade "de um instrumental concentrado na oficina, na fábrica [...] é o produto acabado que viaja". Para Glotz, a produção não demorou a exigir "locais bastante grandes". Ele tinha partido tão longe no seu entusiasmo modernista que ficamos quase aliviados ao ouvi-lo dizer que "a média indústria trabalha ativamente para a exportação; a grande ainda não nasceu. Oficinas e fábricas, sim; usinas, ainda não" (Glotz, 1920, 156-159), o que está longe de corrigir o tiro, principalmente por não sabermos se este "ainda não" reserva alguma coisa para a época helenística ou romana.

Por vezes, ele oscila bruscamente de uma interpretaçção a outra, dizendo, sobre o ramo têxtil, que esta indústria "não tem ainda a intensidade do trabalho industrial: visa-se a qualidade, não a quantidade", para explicar em seguida que quando Síbaris "quiser fabricar ela própria seus tecidos, ela começará isentando de impostos os pescadores e os importadores de púrpura" (Glotz, 1920, 159-160), sugerindo assim uma utilização da fiscalidade com fins econômicos (e até, neste caso, uma "política econômica") que é de um modernismo muito acentuado.

Quanto à cerâmica, ela é um bom teste. Para Glotz, "convém insistir" na cerâmica, que era chamada a fornecer "uma produção intensa". No século VII, em Corinto, a cerâmica "avança ao primeiro plano", há então "uma indústria fortemente organizada" onde "do campo de argila à oficina, a cerâmica faz viver uma boa parte da cidade". É muito ousado de sua parte falar assim de "uma boa parte"! Ele prossegue com uma descrição da indústria de exportação de massa: "para atingir este desenvolvimento, a indústria de Corinto tinha precisado especializar-se. Não há preocupação com "o belo", mas produz-se "às dúzias para uma clientela pouco exigente"; "trata-se de sempre abrir novos mercados aos barcos que partem carregados de vasos de alto a baixo. Os resultados são magníficos. Nenhum produto helênico teve jamais tal suceso nem encontrou mais mercados que a cerâmica de Corinto" (Glotz, 1920, 162-166). Mas Atenas, com uma arte superior -ainda que seus vasos sejam mais caros - substitui Corinto e os pintores coríntios "não encontram mais trabalho". Pintores estrangeiros estabelecem-se em Atenas e "contribuem para uma prosperidade que domina tudo". A cerâmica ateniense é, por conseguinte, "o melhor exemplo de uma indústria poderosa antes das guerras médicas". Como freqüentemente em Glotz, sua excelente erudição evita erros muito grosseiros de análise aos quais ele se dirige em razão de suas escolhas teóricas e ideológicas, ele retifica seu tiro um pouco e in fine, dizendo que "entretanto, uma equipe 
de uma dezena de homens, de uns quinze no máximo, bastava para realizar todo esse trabalho [...] Nada prova que o trabalho que o mundo inteiro pedia ao Cerâmico fosse concentrado em grandes manufaturas; tudo faz supor, ao contrário, que ele se repartia em um grande número de oficinas pequenas e médias" (Glotz, 1920, 168-169).

Tanto quanto o número de metecos, os escravos são importantes neste debate. Para Glotz, era a indústria que "de longe solicitava mais escravos" e "o sistema industrial era tal que ele só podia funcionar movido pela mão-de-obra servil", un ateniense não concebendo "que uma indústria qualquer possa funcionar de outra forma". "Largamente empregada pelos pequenos patrões, a mão-de-obra servil ocupa um lugar quase exclusivo nas indústrias organizadas em oficinas, fábricas ou manufaturas". Lá onde a Antiguidade é diferente, é que "por mais numerosos que sejam no total os escravos industriais, eles não são jamais grupados em grandes massas. Nada de comparável com a grande usina de hoje”. E quando ele volta a ser - muito provisoriamente - primitivista, como aqui, ele é capaz de fornecer análises muito boas, atribuindo a esse fato algumas razões: "a ausência de máquinas, a necessidade de proporcionar o pessoal permanente à demanda constante e segura, a dificuldade de exercer uma vigilância eficaz sobre operários que não têm o estímulo do salário, tudo impede a concentração da indústria e a aglomeração da mão-de-obra" (Glotz, 1920, 248).

Neste debate, modernismo vs primitivismo, no que se refere à indústria, uma expressão define o que poderíamos chamar um "primitivismo mínimo", que até os modernistas (enfim, quase todos) respeitarão: "nada de usinas". Assim, para Glotz, mesmo "se a indústria alimentava uma boa parte da população" (modernismo, mesmo se o número não é definido), "não se segue que tenha sido a grande indústria". Se "sonhamos involuntariamente com as grandes cidades manufatureiras dos tempos modernos", basta, "para não dar a essa concentração um sentido errado", ver que "as oficinas se multiplicam; algumas são importantes o suficiente para que possamos chamá-las de fábricas; nada merece o nome de usina". Mas, em Glotz, a tentação modernista é muito forte e, se ele reconhece que "a pequena indústria domina", ele pensa que "a média desempenha um papel" e que "é penosamente que a grande faz uma vaga aparição" (Glotz, 1920, 315-317). Nada merece o nome, mas ela faz de qualquer forma uma vaga aparição!

E ele então busca as razões: "a primeira razão que impede toda uma série de indústrias de progredir indefinidamente é a persistência do trabalho familiar”, diz Glotz, tão marcado por suas primeiras pesquisas sobre "a solidariedade da família". E ele explica em detalhe o caso do setor têxtil, tão importante para a indústria da sua própria época na definição de um trabalho de usina capitalista. Não há, em todo caso, "nada de parecido com a usina munida de um pessoal numeroso. O maior estabelecimento que conhecemos na Ática, é a fábrica e escudos [...] que conta com 120 escravos". E se, nas minas, chega-se a alugar escravos "por centenas", eles são empregados em grupos de uns trinta em lotes "pouco consideráveis" (Glotz, 1920, 317-320).

Estas oficinas "com pessoal reduzido" não exigiam "grandes investimentos". As grandes fortunas são raras, "mesmo numa cidade como Atenas"; elas são "efêmeras", a indústria "não as atrai particularmente e vive bem sem elas". Isso em parte pois, "com o sistema de adjudicação em pequenos lotes" e "o pagamento antecipado por frações", "não é necessário reunir muito 
dinheiro". E também porque "a usina tem por alma a máquina, e que sem o maquinismo o grande industrial não toma o lugar do artesão. Os escravos bastavam largamente à produção: não era preciso imaginar soluções para a falta ou o alto preço da mão-de-obra". Nas minas, é "a curta duração das concessões de exploração" e "o baixo preço da mão-de-obra" que retardam "o progresso técnico". "É a indústria grega, que nos aparece assim, com utensílios de uma simplicidade primitiva e de uma fraca produtividade" (Glotz, 1920, 320-323).

O sistema das adjudicações é em parte o responsável: "os lotes são muito fracionados, a matéria-prima é fornecida: até os muito pequenos empreendedores podem assim participar em tarefas consideráveis". O produto industrial é caro e o perigo da superprodução é grande. Então, "arranjava-se para que a produção não ultrapassasse as necessidades de forma perigosa: alugavam-se os escravos que não se podia ocupar. O industrial do século IV tinha por preocupação constante limitar a mão-de-obra ao estrito necessário". Glotz também não esquece o aspecto "moral": "nada de produção de massa, apressada, febril, acumulando-se na sombra por um trabalho anônimo", mas sim um trabalho novo a cada vez, sob os olhos do publico, "na alegria" e na busca do belo (Glotz, 1920, 324-328).

Na Grécia, segundo Glotz, "a indústria goza de uma inteira liberdade”. Em geral, não há "um contrato formal", e, "entre empregador, patrão ou cliente, e empregado, operário ou artesão, as relações são juridicamente frouxas e as convenções são livres"; "Jamais os poderes públicos sonharam em limitar a jornada de trabalho". Glotz pensa que "se o trabalho não parece muito duro nas pequenas oficinas, ele se apresenta sob um aspecto totalmente diferente nas minas". Mas, após uma descrição do trabalho, ele julga que não se deve "aplicar ao Láurion as descrições lúgubres que se aplicam às minas do Egito e da Espanha. Apesar de escravos, os mineiros da Ática não eram tratados como forçados. Como os pequenos concessionários se misturavam aos cavadores, isso mostra que essa existência era tolerável" (Glotz, 1920, 330-335). Até as minas eram menos duras na Ática! Nenhuma revolta de massa, e até um teatro em Thoricos, diz Glotz. E isto sem contratos, sem limitações, sem intervenção pública. Um sonho de liberal ...

Quanto às remunerações, de acordo com Glotz, o salário por tarefa tende a substituir o pagamento por dia. Não se trabalhava todos os dias, mas as necessidades eram muito limitadas. E ele afirma, apoiando-se em cálculos, que "enquanto o operário pouco hábil e chefe de família só sobrevive à força de muito trabalho e muitas privações, o operário competente ou o pequeno artesão conseguem criar vários filhos e assegurar-lhes, de acordo com seu trabalho, uma existência de um nível médio ou elevado" (Glotz, 1920, 342).

E, quanto à ausência do maquinismo, ele indica uma causa essencial: "é que o maquinismo é inconciliável com a escravidão, e que a escravidão passava por necessária. A instituição servil, inerente à própria concepção da cidade, eis o que estabelece uma diferença essencial entre a economia antiga e a economia moderna" (Glotz, 1920, 456). Nessa "diferença essencial", nessa "inerência", Glotz é, por uma vez, muito próximo da pesquisa ulterior, de Finley em especial.

Sobre a indústria, portanto, podemos dizer que, salvo em relação a Guiraud, francamente modernista, e, em parte, em relação a Glotz, moderadamente modernista, a maior parte dos autores se inclina claramente em direção a uma interpretação primitivista. 
Sobre o comércio grego, enfim, encontraremos um pouco a mesma configuração, mas o conjunto se desloca um pouco no sentido do modernismo.

Reencontramos, portanto, no início do século XX, o "modernista" extremo, Guiraud, para o qual Corinto, Egina, Atenas, "não se contentavam" com um comércio entre gregos, "seu tráfico tinha já um caráter mundial", e penetrava "até em pleno país bárbaro": "sem dúvida seu campo de ação nos parece muito restrito, se o comparamos ao nosso; mas era uma iniciativa audaz para uma cidade asiática dos séculos VII e VI o fato de enviar seus produtos às profundezas do mar Negro, ao Egito, à Etrúria ou à Espanha. Isto supunha uma força de expansão tão grande quanto a que leva nossos negociantes ao Japão e à Austrália". Mais tarde, isto se alargará ainda mais: "Roma desempenha então um papel equivalente ao de Londres ou de Hamburgo" (Guiraud, 1905, 4).

P. Cloché, por sua vez, vê um aumento constante do comércio ao longo da época clássica e ele dá como prova a tonagem dos navios. Isso é tanto mais importante quanto o comércio era essencialmente marítimo, cujo papel "foi capital no desenvolvimento da economia helênica". Ele examina em detalhe pesos e medidas, moedas, as lojas. Seu modernismo é claro na maneira de transformar obstáculos em vantagens. Assim, as estradas são muito medíocres e os rios muito insuficientes como meio de transporte, mas ele acrescenta que pelo menos "eles não eram sério entrave à circulação, e podia-se com frequência transpôlos a pé". Assim, "na economia helênica, em geral, a atividade comercial teve um espaço importante, que tendia até a tornar-se preponderante em várias cidades, como Atenas, Corinto, Mégara e outras (Cloche, 1931, 75-88). Ora, para um primitivista, é a agricultura que é sempre, e em toda parte, preponderante.

Quanto a Glotz, ele se torna, no que se refere ao comércio, nitidamente mais modernista. Assim, segundo ele, no prosseguimento da colonização arcaica, os gregos "continuaram a difundir sua civilização", não tendo mais o medo "de morrer de fome", e "enfim eles detinham os mercados onde se concentravam as riquezas do mundo inteiro". Sua análise do comércio arcaico é um encadeamento otimista de "progressos" de todo tipo: estradas, portos, novos navios, moedas. Até a introdução da escrita é "intimamente ligada à do comércio (enquanto outros autores destacarão causas políticas, literárias, religiosas), estabelecendo assim ligações entre comércio e progressos em todos os níveis. Neste autor, as explicações pelo comércio se multiplicam, muitas vezes redutoras, como quando ele explica que "as festas délicas consagravam a independência comercial da raça jônica". Sua confiança nos efeitos civilizadores do comércio é tão absoluta que ela se torna até comovente por vezes, como quando ele explica que nos confins do Ponto Euxino, "em Berezan, uma ilhota de pescadores reabastecida pelos milésios, quase todos sabiam ler e escrever"... O comércio é tão importante que ele até causa guerras; a destruição de Síbaris, em 511, mostraria "que ferocidade podia atingir, na Grécia do século VI, a concorrência comercial" (Glotz, 1920, 135-149).

É claro que o comércio de varejo era mal visto, mas o comércio de atacado era muito apreciado; é claro que o comércio terrestre atingia "preços incríveis", mas por mar tudo era tão barato que "por duas dracmas pode-se ir ao Egito ou ao Ponto Euxino com mulher, filhos e bagagens"; e isto numa época de grandes progressos: os barcos se aperfeiçoaram e a velocidade foi dobrada ou triplicada em relação à época homérica (e, por detrás desses 

segundo os positivistas.

cálculos, parece que escutamos os seus contemporâneos falando com extase das velocidades dos trens modernos). A imagem do comércio grego em Glotz é uma imagem de superatividade (Glotz, 1920, 346-352).

Passemos a outros elementos: liberdade e expansão. Em Atenas o comércio é livre, "mas a liberdade humana nunca é absoluta". Então, "a cidade intervém, em nome do interesse geral, para assegurar a lealdade das operações". Mas trata-se de uma simples supervisão geral, salvo em relação ao comércio de grãos, campo em que ela "não quer mais ouvir falar de liberdade" (Glotz, 1920, 353-354). O comércio se torna tão importante para a prosperidade e o poderio da cidade, e os atenienses estavam tão conscientes disso, que "era justo e fatal que à frente do governo fossem colocados un dia os mais destacados comericantes do Pireu. O imperialismo era uma coisa deles". Glotz vai muito longe aqui, nesta formulação de uma cidade imperialista-comerciante. E, quando ele se lança na explicação do projeto político e comercial, não vemos mais qualquer fronteira entre análise e aprovação: "era preciso que Atenas tivesse um império, e que por esse império ela exercesse a hegemonia na Grécia e que a Grécia comandasse os bárbaros, para que todos, bárbaros e gregos, fossem, sem resistência possível, os fornecedores e os clientes dos atenienses" (Glotz, 1920, 374).

Com Jardé, o comércio grego é sensivelmente diferente. A cidade "vigia o comércio", o Estado "intervém para proteger o consumidor", ele "persegue os manipuladores, controla os preços"; quando se trata de mercadorias de primeira necessidade "a intervenção do Estado é ainda mais ativa", a cidade devia "assegurar aos cidadãos víveres abundantes e a bom preço", "preocupa-se com o abastecimento do mercado e em impedir a especulação", os mercadores domiciliados na Ática são proibidos "de levar o grão alhures", é "proibido fazer empréstimos de risco sem que o tomador do empréstimo se comprometa a trazer um carregamento de grão ou outros gêneros úteis". A cidade controla as entradas, o preço do grão, a relação entre o preço do cereal e o da farinha, entre o da farinha e o do pão. Se a necessidade aparece, a cidade se compromete a distribuir ou a vender mais barato o grão aos cidadãos pobres (Jarde, 1914, 244-246). Jardé é neste ponto próximo desta "cidade dos consumidores" cara a Weber e a Hasebroek.

É verdade que, segundo Jardé, "nas cidades, muitos cidadãos vivem do negócio", mas freqüentemente, como em Atenas e no Pireu, "o grande comércio está em boa parte entre as mãos dos metecos”. O Estado intervém no comércio e tira proveito através de direitos de alfândega, mas "não se trata de tarifas protecionistas favorecendo a produção nacional, mas de simples medidas fiscais", na entrada como na saída dos produtos, aliás. A cidade "pode ela própria fazer comércio, estabelecendo monopólios, controlando tal ou tal produto que ela revende taxando a um preço superior" (Jarde, 1914, 244). Mas por razões políticas e estratégicas mais que por motivos econômicos.

Francotte vai no mesmo sentido. O comércio ateniense "era, sobretudo, um comércio de importação e um comércio de trânsito referente principalmente aos produtos do solo e às matérias-primas e não aos produtos fabricados" é preciso relativizar a dimensão do comércio grego; mesmo o porto de Delos no seu apogeu (época romana, portanto a mais favorável em princípio à tese de um comércio intenso) tem dimensões apenas modestas (praia de $800 \mathrm{~m}$, cais de $250 \mathrm{~m}$ ), se comparado com os portos modernos (Francotte, 1900, v1, 109-118). Francotte faz uma leitura muito perspicaz das afirmações do Velho Oligarca acerca do afluxo 
de mercadorias a Atenas graças ao império sobre o mar, e de Tucídides fazendo Péricles afirmar que "tudo penetra aqui de todos os pontos do mundo, por causa da grandeza da cidade", e Francotte conclui: "portanto, um comércio de importação". Para Francotte, os atenienses pagavam tudo isso com vinho e azeite é claro (mas eles seriam bem insuficientes), mas, sobretudo, com os rendimentos do porto do Pireu, as "somas enormes" do império colonial, e a prata do Láurion (Francotte, 1900, v1, 119-122). Portanto, cidade dos consumidores e comércio de importação. Quanto a essa imagem de "falta", podemos citar sua apreciação sobre as sociedades. Para Francotte, o grego "só concebe a sociedade sob a forma da confraria", ele inclui sempre nela "a idéia religiosa". Para ele, "esta é uma prova de concepções ainda primitivas e o sinal de um estado econômico pouco desenvolvido" (Francotte, 1900, v2, 199-201). Análise histórica um pouco errada, aliás, mas onde vemos claramente que, para ele, a pequena autonomia do econômico em relação ao religioso é um sinal de primitivismo econômico.

Seria fácil multiplicar os exemplos. Observemos simplesmente o de J. Laurent, quando ele diz que "o grande comércio de uma cidade grega não afetou muito a vida material da massa de seus habitantes, pois foi um comércio de trânsito". Como ele não correspondia a uma produção local, "o conjunto da Grécia permaneceu pobre". Mesmo onde o comércio foi próspero, ele é realizado por estrangeiros, libertos ou proletários, "os quais se apressam, logo que adquirem alguma fortuna, em se tornar proprietários rurais", e isso porque o comércio não é muito bem visto. E, além disso, segundo Laurent, pelo fato dele ter reunido estrangeiros e desempregados com objetivos distintos dos agricultores, ele forneceu aos políticos "uma massa de manobra" que foi "uma causa de problemas sociais" (Laurent, 1933, 131-134).

Alguns assuntos são mobilizados no debate, num sentido ou noutro. Assim, por exemplo, a colonização arcaica. Segundo Francotte, a colonização arcaica tem por objetivo buscar terras: "eles vão buscar longe terra a ser dividida", e trata-se de um problema constante; até em Atenas, no século V, "Péricles é obrigado a transportar ao ultramar uma parte do proletariado ateniense" (Francotte, 1922,12). Para Jardé, a colonização é o resultado da falta de terras, não tanto em termos absolutos, mas em razão de sua má distribuição. Mas o aumento da população, a urbanização, a riqueza mobiliária fazem com que, desde a segunda metade do século VII "os grandes centros comerciais", "têm necessidade de estabelecer relações com o estrangeiro", e se "os primeiros colonos tinham buscado terras, os do século VI partem à conquista de matérias-primas e mercados" (Jarde, 1923, 122-125; Jarde, 1914, 7). Enquanto a colonização agrária de Francotte vai no sentido primitivista, a de Jardé, em duas etapas, representa um compromisso. Para Glotz, "por mais pronunciado que seja o caráter agrário da colonização helênica, ela não teve apenas por objetivo a aquisição de terras e por agentes os cultivadores"; ainda que tenha sido esse o objetivo primordial, "a prosperidade industrial e comercial, o desenvolvimento urbano vinham como acompanhamento [...] é impossível que os gregos não tenham sido levados em um certo número de pontos à busca da riqueza mobiliária" (Glotz, 1920, 122). Ele se limita, aqui, a uma posição "média", ainda hoje perfeitamente sustentável. Mas, a cada vez que ele se afasta dessa posição média, é no sentido modernista: "é certo que os gregos só excepcionalmente tiveram colônias de exploração: mas suas colônias de povoamento não foram todas exclusivamente agrícolas, mesmo no início. Estes emigrantes que partiam sem espírito de retorno não 
buscam sempre terras, eles sonhavam também com o negócio". Um primitivista nem menciona "colônias de exploração", não admite senão colônias agrícolas no início, e só vê o objetivo da terra na cabeça dos emigrantes no barco.

Moeda e bancos são assuntos abençoados para o modernismo. Assim, Glotz vai da nuança ao exagero. Ele começa reconhecendo que nos "mais belos séculos da Grécia, a economia natural conserva uma forte vitalidade", dominando nas regiões afastadas, mas afirma que "nas grandes cidades, é verdade, todas as instituições repousam sobre a economia monetária". Se, "mesmo na Ática, o regime natural está longe de haver desaparecido totalmente", todas essas exceções não impedem a economia da Grécia clássica de ser monetária". Mas não se trata de um período "onde o regime monetário, em pleno desenvolvimento, possa dar nascimento a um crédito indefinido, a um capitalismo frenético" (Glotz, 1920,: 277-278). Muito bem. Mas, um pouco adiante, ele afirma, acerca dos bancos, que "nada mostra melhor que sua história a rapidez com a qual os negócios se desenvolveram na Grécia do século V". Em desenvolvimento acelerado, "a união entre os bancos e o comércio no século IV deu um súbito impulso à especulação". E ele fala de "verdadeiras manobras de bolsa de valores" (Glotz, 1920,: 361-365). Especulação, golpes de bolsa, a imagem é de uma verdadeira Wall Street na ágora!

Mas a força das idéias primitivistas é grande e muitas vezes os autores atraídos por uma interpretação modernista devem levar isso em conta. Assim, acerca da especialização do trabalho, Glotz começa afirmando que a Grécia conheceu a especialização nas funções públicas e nas privadas, e que isso se desenvolveu muito nos séculos V e IV. Platão e Xenofonte, segundo ele, viram aí um meio de aumentar a qualidade mas também a quantidade dos produtos (Glotz, 1920, 265 sq). Quanto aos primitivistas, eles excluíam esta preocupação quantitativa. Mas, diz Glotz, se há "uma notável especialização dos ofícios", "não se deveria dar a este fenômeno o sentido que a economia política normalmente lhe atribui", pois "nos tempos modernos, a forte divisão do trabalho acompanha o desenvolvimento do capitalismo e da grande indústria", enquanto que "na Grécia antiga, são precisamente os empresários mais ricos que dirigem ao mesmo tempo indústrias diversas ou reúnem na mesma fábrica várias produções” (Glotz, 1920, 274). Na Antigüidade, a divisão do trabalho "não é função do maquinismo", "não caracteriza um regime de grandes usinas, mas uma indústria pequena ou média que se dirige diretamente a uma clientela difícil". Há, portanto, o antigo e o moderno, diferentes. Mas ele afirma, apesar disso, que "o mundo grego conhece a divisão do trabalho internacional". Simplesmente, apesar deste trabalho ser muito intenso, ele não se concentra "em estabelecimentos munidos de mecanismos monstruosos" e as classes trabalhadoras não dependem "de algumas firmas todo poderosas" (Glotz, 1920, 275). Glotz demonstra aqui um modernismo moderado.

Uma questão importante no debate era a de saber se havia uma concorrência entre trabalho livre e trabalho escravo. Para Guiraud, "o homem livre que queria ganhar a vida com seu trabalho enfrentava a concorrência do escravo". Ele explica que a remuneração do trabalho era calculada em relação às necessidades de um escravo e não de um livre, e ele faz o paralelo com os imigrantes na economia do seu tempo. Por outro lado, a greve não era possível, pois ela provocaria um recurso imediato a outros escravos. A escravidão "tirava trabalho" dos livres, e até muito trabalho. Ora, para ele, a escravidão não cessou de aumentar em número (ele dá uma avaliação elevada). Os senhores deviam empregar os escravos o 
máximo de tempo possível, pois sua manutenção custava caro, e "esta invasão contínua de trabalhadores exóticos, para os quais os senhores buscavam a qualquer preço um emprego, tinha esse efeito nefasto de aumentar provavelmente o embaraço do camponês ou do artesão em busca de ocupação" (Guiraud, 1905, 69-71; 127-129). Segundo Francotte, não é bem assim; "a concorrência servil é um mal do qual sofreu a antiguidade grega, uma ferida que a sociedade carregou, mas uma ferida menor e menos profunda do que se diz geralmente". O trabalho livre continuou a existir num equilíbrio com a escravidão; num equilíbrio precário, mas que, segundo ele, não foi rompido. Esta apreciação é claramente ligada ao seu primitivismo, pois se, na opinião dele, a escravidão não dominou, isso aconteceu porque o mercado era estreito e a concentração das riquezas era moderada. Francotte realiza cálculos muito complexos (preços, salários, juros, custos) e chega à conclusão que "na grande indústria, nos trabalhos das minas, nas profissões puramente corporais, o escravo devia prevalecer. Ele fornecia um trabalho mais regular e mais disciplinado"; e lá onde o trabalho especializado necessitava de um longo aprendizado, lá onde os mercados não eram regulares, o trabalho livre era mais adaptado pois podia-se dispensá-lo mais facilmente" (Francotte, 1900, v2, 18, 27-28). E, numa outra passagem, Francotte chama a atenção para a inscrição do Erecteion e realiza uma análise que será retomada por todos os primitivistas até Finley. Ele observa que "no mesmo grupo de trabalho, cidadãos, metecos e escravos recebem salários idênticos. Este ponto é de uma extrema importância. Ele mostra que a força de produção do escravo não está abaixo da do homem livre"' (Francotte, 1900, v1, 319). Produtividade equivalente, paridade de salário, e em consequência, nada de concorrência. Isto se tornará um artigo de fé primitivista.

O trabalho e a idéia de trabalho são discutidos, inaugurando assim uma bela polêmica nos estudos clássicos - que examinaremos em outro local - que, de Gernet e Glotz até Vernant, fará muito barulho. Para Guiraud, na época homérica o trabalho "era muito estimado. Nem se colocava a questão de saber se ele era honrado ou não, a coisa era óbvia. Os maiores personagens trabalhavam com as mãos e se vagloriavam disso", e "há tão pouca tendência então a desprezar o trabalho que o poeta obriga até os deuses a trabalhar" (Guiraud, 1905, 30-32). A. Croiset examina um por um os textos sobre o desprezo ao trabalho, os textos em honra do trabalho, e argumenta: "não acusemos a sociedade ateniense, em geral, de ter desprezado o trabalho. Ela era, no seu conjunto, laboriosa demais para ter caído nessa armadilha". Esta "sociedade laboriosa no seu conjunto" tem enormes consequiências para a interpretação da cidade grega. É também um traço de modernismo: isto quer dizer que eles obrigatoriamente devem ter honrado o trabalho, visto que eram como nós. Discutível, e muito discutida, esta visão abre a ele possibilidades de interpretação interessantes. Ele é um dos raros na época a ver coisas positivas nesses homens de Estado influentes saídos "da média burguesia", como Cleon e Hyperbolos. "Isso escandaliza os aristocratas, porque é novidade. Mas também serve para provar que o trabalho não era tão desprezado pela opinião pública com se pensa frequentemente" (Croiset, 1920, 175-176).

As relações entre Estado e economia também interessam. Para Glotz, "os direitos aduaneiros têm por objetivo fornecer ao povo recursos financeiros e não o de contrariar o jogo natural das trocas"; muito baixos, além disso, eles não dificultam o comércio, nem na entrada nem na saída dos produtos (Glotz, 1920, 356). Jardé, que também só vê "puras medidas fiscais", explica várias exceções, que ele atribui à razão de Estado (guerra, comércio de grãos, produtos estratégi- 

segundo os positivistas.

cos) muito mais que a motivações econômicas (Jarde, 1923, 311). Francotte explica que "entre os meios mais usados, nos Estados modernos, para desenvolver a indústria, encontram-se os direitos de entrada e, em termos mais gerais, a legislação aduaneira. Os antigos entenderam bem sua importância". Ainda que, com maior frequiência, as razões sejam fiscais, "há também alguns exemplos de proibições por razões econômicas", sem falar de razões políticas, lançadas sobre produtos ou sobre Estados, como Rodes arruinada quando Delos foi declarado porto franco exatamente com esse objetivo. Mas ele reconhece que havia um mínimo de intervenção na economia, nenhuma regulamentação do trabalho, nenhum controle higiênico, nenhuma fixação de níveis de salário. Havia certo controle, mais nenhum direcionamento dado pelo Estado: "os agoranomos só intervinham em casos particulares, e não através de medidas gerais, em vista de prevenir as fraudes e não para bloquear a alta natural de uma mercadoria". Para Francotte, "a regulamentação teria sido relativamente fácil", mas ele não conhece exemplo, para os produtos industriais pelo menos, de "fixação direta dos preços" (Francotte, 1900,v2, 130-141). Portanto, um Estado não-intervencionista.

Nesta interrogação sobre o modernismo ou o primitivismo da economia grega, muitos jogam com as épocas; em geral as opiniões são moduladas e o quadro geral é o de uma modernidade que progride nas épocas mais recentes. É raro ver alguém, como Aymard, pensar que já na época minóica havia uma indústria "atestada" que "gerava um comércio muito intenso"; era preciso até "abastecer a indústria em matérias-primas, muitas vezes desconhecidas na ilha, e também vender seus produtos fora", e vemos "pela primeira vez no mundo antigo, uma vida econômica dominada pelo comércio marítimo" (Aymard, 1953, 218). "Dominada", nada mais nada menos... Sua cegueira modernista o leva a ver uma "expansão comercial" nos mecanismos de imposição e redistribuição dos palácios minóicos e micênicos, por exemplo (Aymard, 1953, 227).

Outros, apesar de modernistas, jogavam melhor com as variáveis, seja Guiraud com a variável cronológica, vendo, na época homérica, no regime patriarcal, um obstáculo ao desenvolvimento da indústria e, ao mesmo tempo, uma divisão do trabalho ainda "na infância" (Guiraud, 1905, 39); ou ainda Jardé, jogando com a variável geográfica, vendo na rusticidade e no despojamento espartanos, menos a obra deliberada de um Licurgo que "a expressão natural de uma economia agrícola e fechada" (Jarde, 1923, 171).

A época arcaica (urbanização, colonização, moeda) é um momento privilegiado para os modernistas. O que provoca reações. Para Francotte, "não se deve exagerar a mudança. Para começar, ela não é geral: uma grande parte das cidades gregas nunca saíram de um regime quase exclusivamente agrícola. Em seguida, lá onde a mudança aconteceu, ela não foi tão profunda quanto poderíamos pensar" (Francotte, 1900, v1, 24-31).

Deixemos de lado a época clássica, sobre a qual se refere a maior parte da análise acima, observando simplesmente que, se ela marca um apogeu econômico em relação aos séculos anteriores, e mesmo para um modernista como Glotz, ela "ainda não conseguiu reunir os homens numa unidade econômica", "não apresenta a eles ainda, nem mesmo sob uma forma puramente material, esta concepção da 'humanidade' que brilhará sobre o mundo helenístico" (Glotz, 1920, 377). Na época helenística, a situação muda; há um "cosmopolitismo", "a diversidade dos Estados não é obstáculo à unidade de civilização, condição de um mercado universal”, a divisão do trabalho e a especialização são levadas muito longe, 
as associações profissionais tomam um conteúdo econômico, organizando-se em "verdadeiros sindicatos", a circulação monetária se torna "de uma intensidade desconhecida" (Glotz, 1920, 280-289). Segundo Francotte, na época helenística a política "não é idealista; é a política prática conduzida por homens de negócios; é o mundo visto da Bolsa" (Francotte, 1900, v1, 41). Este mundo helenístico é decididamente moderno: há um declínio da escravidão, a técnica "parece na véspera de aplicar em larga escala as descobertas da ciência à indústria", em toda parte, diz Glotz, progride a divisão do trabalho, a iniciativa econômica do Estado e os monopólios, a economia natural recua em toda parte, mesmo no Egito. Mas, justamente, trata-se de um mundo cada vez menos "grego". Segundo Glotz, a indústria encontra condições ideais, mas fora da Grécia propriamente dita. Alexandria conta com "centenas de milhares de operários", enquanto que a Grécia, pobre demais, pouco povoada demais, afastada demais do novo mundo oriental, "agoniza" em conflitos sociais. No oriente, há um "extraordinário desenvolvimento da vida urbana", jamais na história do mundo, excetuando-se na América do século XIX, vê-se surgir do solo tantas cidades de uma vez, e "Alexandria vai substituir por muitos séculos o Pireu, na condição de empório do comércio universal". Alexandria e Rodes são cidades e portos "modernos". Em suma, a época helenística é moderna, mas ela é cada vez menos grega.

Podemos constatar que o vocabulário de análise econômica, utilizado de maneira muitas vezes inocente, leva a confusões e anacronismos. Assim, Aymard fala da existência, em certas cidades ativas, de uma "burguesia" (Aymard, 1953, 298). Aymard é, aliás, um caso interessante. Parece que, em 1953, antes da difusão das idéias de Finley, o "modernismo" tenha avançado posições na França. Assim, ele fala de uma "economia industrial e comercial" que "venceu" em algumas regiões. Mas a força dos argumentos "primitivistas" tinha sido suficientemente importante na primeira metade do século para impor-lhe, através de um jogo de argumentos que se parece com uma gangorra - e que desconcerta o leitor contra-exemplos em sentido inverso. Ele busca claramente se "cobrir" num debate complicado que já durava várias décadas (Aymard, 1953, 262, 264).

Para os modernistas mais antigos e convictos, como P. Guiraud, o modernismo da economia antiga é devido, em última análise, à imutabilidade do espírito humano: "Os gregos e os romanos tinham no mais alto grau o gosto dos negócios e o espírito de especulação", e isso porque "não se esperou até nossos dias para compreender que a satisfação dos apetites materiais é a primeira necessidade do homem, e que este é o mais poderoso motor da máquina social como da máquina humana” (Guiraud, 1905, 4).

Assim como há uma "burguesia", há também “capitalistas": para Guiraud, eles até se associam em companhias organizadas "sobre o modelo das nossas", numa assimilação total entre o ontem e o hoje (1905) (Guiraud, 1905, 9). Na outra ponta do meio século estudado, Aymard (1953) falará ainda dos "capitalistas romanos" (Aymard, 1953, 322), mas afirma que, na Grécia, "a acumulação capitalista permanece muito moderada" (Aymard, 1953, 334). Francotte mantém a confusão, falando de grandes nobres porprietários de vastos domínios como dos "capitalistas da época" (Francotte, 1922, 48), ou ainda dos "capitalistas" da pequena indústria (Francotte, 1900, v2, 21). Portanto, mesmo um primitivista como Francotte utiliza o termo "capitalista"; mas, na maior parte das vezes, o termo se refere livremente a "possuidor de capitais", na verdade. Mas, segundo Laurent, "os Gregos conhe- 
ceram o capitalismo" (Laurent, 1933, 131); mas se trata de uma "prática econômica (moeda difundida, empréstimo a juros, etc.) como nós diríamos, mais que de um "sistema econômico". Mas será necessário esperar por Aymard para ouvirmos claramente que "em nenhuma parte houve 'capitalismo' " (Aymard, 1953, 264); e o uso repetido da palavra provocou durante o todo o período uma grande confusão, que quase sempre agiu no sentido de reforçar as idéias modernistas.

O que torna este debate difícil é que, no século XX, ele já é herdeiro de uma polêmica que vem do século XIX. Muitas vezes os autores buscam se libertar da necessidade de escolher, ainda que optem por uma linha em suas próprias análises. Assim, Glotz resume, já em 1920, as duas posições e diz: "se refletirmos um instante diante desses quadros sucessivos, veremos o quanto são frágeis as teorias emitidas apressadamente acerca da economia dos gregos. Nenhuma resiste à corrente turbulenta da história. Quanto mais elas são peremptórias, mais elas são ruinosas, e seu erro aparece em proporção com seu exclusivismo". Ele não aceita Rodbertus e Bücher, para os quais a economia antiga ficou sempre limitada à casa, e a autarquia familiar só adquiria fora, como complemento, bens em quantidade insignificante"; ele não aceita também "os historiadores que sustentam, como Eduard Meyer e Pöhlmann, que depois de ter ultrapassado o estádio da economia doméstica, os gregos chegaram rápido a uma economia não apenas urbana, mas mundial, e que, por isso mesmo, eles ouviram soar com insistência as reivindicações socialistas do operariado". Ora, para ele, trata-se da visão de "doutrinários alemães" que não enxergam as interferências entre os regimes econômicos” em todas as épocas da história grega (Glotz, 1920, 455-456). Ora, se a economia grega não é, talvez, para Glotz, uma economia moderna no sentido do capitalismo industrial, ela se parece muito com a economia "moderna" da expansão colonial e mercantil européia de antes da revolução industrial (Glotz, 1920).

No outro sentido, o primitivista, Francotte se insurge: "lendo certas descrições de Atenas ou de Corinto, percebemos facilmente que elas foram escritas no século da grande indústria, e acreditaríamos estar vendo Manchester ou Birmingham". Ele critica os exageros acerca "da prodigiosa fortuna econômica", num país (a Grécia) "onde todos viviam do comércio", e insiste sobre "a pequena importância da indústria" na Grécia (Francotte, 1900, v1, 2-7). Ele se pergunta "onde está essa produção em massa (Massen-production), essa produção na fábrica (Fabrik mässig) da qual tantos autores modernos nos falam?" (Francotte, 1900, v1, 158). Ele critica os autores alemães, e só concorda com Bücher (Francotte, 1900, v1, 287).

Os autores positivistas, à imagem de Francotte, fornecem análises muitos longas, muito técnicas, muito ricas em informação, mas surpreendentemente pobres quando se trata de conceitos, de debates históricos sobre a sociedade grega. Vemos o efeito da idéia positivista do saber por acumulação. Compara-se com o "nós" (ou seja, a época dos autores) e julga-se. É interessante ver, por exemplo, Francotte repetir continuamente ao longo de 700 páginas do seu livro sobre a indústria grega que a mesma não se compara com a indústria moderna. Os homens do final do século XIX e do início do século XX eram tão fascinados com o progresso técnico da Europa que eles eram incapazes de relativizar este critério de mensuração.

Herdado, portanto, do século XIX, o debate sobre a natureza da economia grega atinge um máximo de intensidade nos positivistas da primeira metade do século XX. Há modernistas e 
primitivistas. Mas, contrariamente ao que nos fez pensar uma bibliografia de inspiração finleyana (que, quanto a ela, no máximo, reconhecia em Bücher, Gernet e Hasebroek alguns predecessores) que se apresentava como uma reação ao modernismo que segundo ela predominava, a cidade grega positivista era já uma cidade mais primitiva que moderna.

\section{Referências bibliográficas e bibliografia complementar}

AMPOLO, C. (Org.) La città antica. Guida storica e critica.Bari: Laterza, 1980.

AYMARD, A. "Liberté, patrie, factions" Revue des Études Anciennes, 49: 321-326, 1947. L'Orient et la Grèce antique. Paris: PUF, 1994 [1953].

BAILEY, C. \& FINLEY, M. (Org.). L'héritage de la Grèce et de Rome. Paris: Robert Laffont, 1992.

BIARD, A.; BOUREL; D. BRIAN, E. (Org.). Henri Berr et la culture du XX e siècle. Histoire, science et philosophie. Actes du Colloque International 24-26 octobre 1994. Paris: Albin Michel, 1997.

CAMERON, A. (Org.). History as text. The writting of ancient history. Londres: Duckworth, 1989.

CANFORA, L. "Antiquisants et marxisme", Dialogues d'Histoire Ancienne, 7: 429-436, 1981.

Ideologias de los estudios clásicos. Madri: Akal, 1991.

CARCOPINO, J. "Histoire de l'ostracisme athénien”. Mélanges d'Histoire Ancienne, 25. Paris: Félix Alcan, 1909.

CASSIN, B. (Org.). Nos Grecs et leurs modernes. Paris: Seuil, 1992.

CAVAIGNAC, E. L'économie grecque. Paris: Plon, 1951.

CLOCHE, P Les classes, les métiers, le trafic. Paris: Les Belles Lettres, 1931.

La démocratie athénienne. Paris: PUF, 1951.

Le monde grec aux temps classiques. Paris: Payot, 1958.

COHEN, R. La Grèce et l'hellénisation du monde antique. Paris: PUF, 1939.

CROISET, A. Les démocraties antiques. Paris: Flammarion, 1920.

CROISET, M. La civilisation de la Grèce antique. Paris: Payot, 1994 [1922].

DI DONATO, R. "La cité de Fustel à Glotz; méthode historique et science sociale" in "Poikilia" Études offertes à Jean-Pierre Vernant. Paris: Editions de l'EHESS, 1987, 451-461.

DROIT, R.-P. Les Grecs, les Romains et nous. L'Antiquité est-elle moderne? Paris: Le monde Editions, 1991.

FESTUGIERE, A.-J. Liberté et civilisation chez les Grecs. Paris: Editions de la revue des jeunes, 1947.

FLACELIERE, R. La vie quotidienne en Grèce au siècle de Périclès. Paris: Hachette, 1959. 
FRANCOTTE, H. L'industrie dans la Grèce ancienne. New York: Arno Press, 1979, 2 v [Liège: Bibliothèque de la Faculté, 1900-1901].

. La polis greque. Paris: Paderborn, 1907.

Histoire politique de la Grèce ancienne. Bruxelles: A. Dewil, 1922.

GLOTZ, G. La solidarité de la famille dans le droit criminel en Grèce. New York: Arno Press, 1973 [Paris, 1904]

. Le travail dans la Grèce ancienne. Paris: Felix Alcan, 1920.

Histoire Grecque. Paris: PUF, 1948 [1926], 2v.

La cité grecque. Paris: Albin Michel, 1988 [1928].

GRIMAL, P. Les erreurs de la liberté dans l'Antiquité. Paris: Les Belles Lettres, 1990.

GUIRAUD, P. Etudes économiques sur l'Antiquité. Paris: Hachette, 1905.

HARTOG, F. Le XIXe siècle et l'histoire. Le cas Fustel de Coulanges. Paris: PUF, 1988.

HATZFELD, J. Histoire de la Grèce ancienne. Paris: Payot, 1950 [1926].

ISAAC, J. Les oligarques. Paris: Ed. de Minuit, 1945.

JACOB, O. Les esclaves publicas à Athènes. New York: Arno Press, 1979 [Paris: Champion, 1928].

JARDE, A. La Grèce antique et la vie grecque. Paris: Delagrave, 1996 [1914].

La formation du peuple grec. Paris: Albien Michel, 1938 [1923].

Les céréales dans l'Antiquité grecque. La production. Paris: De Boccard, 1979 [1925].

LAURENT, J. Essais d'histoire sociale. La Grèce antique. Paris: Les Belles Lettres, 1933.

MOMIGLIANO, A. Problèmes d'historiographie ancienne et moderne. Paris: Gallimard, 1983.

PICARD, C. La vie privée dans la Grèce classique. Paris: Rieder, 1930.

ROMILLY, J. de. Problèmes de la démocratie grecque. Paris: Hermann, 1975.

VERNANT, J.-P. Entre mythe et politique. Paris: Seuil, 1996.

VIDAL-NAQUET, P. La démocratie grecque vue d'ailleurs. Paris: Flammarion, 1990.

VOGT, J. "La schiavitù antica da Humboldt a oggi” in L. SICHIROLLO (Org.), Schiavitù antica e moderna, problemi, storia, istituzioni. Nápoles: Guida Editori, 1979, 205-224.

TRABULSI, José Antonio Dabdab. Manchester ou Tombouctou? L'économie de la "cité grecque" selon la vision des positivistes. Classica, São Paulo, 13/14, p. 411-431, 2000/ 2001 .

RESUMÉ: Ce travail a le but d'étudier la vision des historiens "positivistes" de la cité grecque, notamment en matière d'économie. Ainsi, il apparaît que, contrairemente à une idée reçue, leur cité grecque soit déjà primitiviste ou plutôt primitiviste. Mais il n'y a pas d'unanimité. Nous essayons de dégager certaines motivations et certains conditionnements dans leurs choix. Ce texte est 
une partie d'un ensemble de travaux sur les "cités grecques" du XX e siècle. II a été écrit avec l'appui de la CAPES (Ministère de l'Education du Brésil).

MOTS-CLÉS: Cité grecque; historiographie; positivisme; histoire grecque; pensée française. 